\title{
Will coastal wetlands continue to sequester carbon in response to an increase in global sea level?: a case study of the rapidly subsiding Mississippi river deltaic plain
}

\author{
R. D. DeLaune · J. R. White
}

Received: 25 September 2009 / Accepted: 25 February 2011 / Published online: 12 May 2011

(C) The Author(s) 2011. This article is published with open access at Springerlink.com

\begin{abstract}
The highly visible coastal phenomenon of wetland loss in coastal Louisiana (LA) was examined through the prism of carbon accumulation and loss. Carbon storage or sequestration in rapidly subsiding LA coastal marsh soils was based on vertical marsh accretion and aerial change data. Marshes sequester significant amount of carbon through vertical accretion however, large amounts of carbon previously sequestration in the soil profile is lost through annual deterioration of these coastal marshes. Hurricanes, such as Katrina and Rita, have triggered instantaneous large carbon losses of sequestered soil carbon through the destruction of large areas of marsh. This analysis shows proposed coastal restoration efforts will not be sufficient to restore carbon losses by storms and marsh deterioration. Further, we have estimated the economic benefit of carbon sequestration for coastal wetland restoration efforts. Results show that LA coastal marshes may not serve as a net sink of carbon. These results may serve as a predictor of the impact of future predictions of increasing global sea level rise on carbon sequestration for other coastal regions.
\end{abstract}

$\begin{array}{ll}\text { Abbreviations } \\ \mathrm{CO}_{2} & \text { Carbon dioxide } \\ \mathrm{C} & \text { Carbon } \\ \mathrm{N}_{2} \mathrm{O} & \text { Nitrous oxide } \\ \mathrm{CH}_{4} & \text { Methane } \\ \mathrm{SOM} & \text { Soil organic matter } \\ \mathrm{USGS} & \text { United States Geological Survey } \\ \mathrm{CLEAR} & \text { Coastal Louisiana Ecosystem Assessment and Restoration } \\ \text { IPPC } & \text { Inter-government Panel on Climate Change } \\ \text { CCX } & \text { Chicago Climate Exchange }\end{array}$

R. D. DeLaune $(\bowtie) \cdot$ J. R. White

Department of Oceanography and Coastal Sciences, School of Coast and Environment, Louisiana State University, Baton Rouge, LA 70803, USA

e-mail: rdelaun@1su.edu 


\section{Introduction}

Global warming has become a major worldwide concern and is largely driven by increasing concentrations of atmospheric $\mathrm{CO}_{2}$ and other greenhouse gases (e.g., $\mathrm{CH}_{4}$ and $\mathrm{N}_{2} \mathrm{O}$ ). Coastal wetlands are sensitive to global climate change while playing an important role in the global carbon (C) cycle (Chmura et al. 2003; Rabenhorst 1995; Choi and Wang 2004). However, the dynamics of C cycling in coastal wetlands and response to sea level change associated with global warming is poorly understood (Erwin 2009). A number of approaches have been proposed to reduce $\mathrm{CO}_{2}$ concentrations in the atmosphere. One ecological approach is to take advantage of the ability of terrestrial ecosystems to fix and sequester atmospheric $\mathrm{C}$ in the soil (Armentano and Menges 1986). The potential of soil C storage, including coastal wetland soils, is enormous (Rabenhorst 1995; Eswaran et al. 1995). The estimated C sequestration through management of world soils alone could range between 1.2 and 2.6 Pg C year ${ }^{-1}$ (Lal 2001).

Histosols (peat soils) form within wetland environments and have the highest $\mathrm{C}$ content of all the soil orders (Bridgham et al. 2006). This high $\mathrm{C}$ content is due to the fact that wetland ecosystems have the highest net primary production rate of all terrestrial ecosystems (Amthor and Huston 1998; Keddy 2000) coupled with a slow rate of organic matter (OM) decomposition due to prevailing anaerobic conditions in the flooded soils (Stevenson and Cole 1999; White and Reddy 2000). Therefore, wetland soils create an important sink for atmospheric $\mathrm{CO}_{2}$.

Wetland soils are estimated to contain about $20-25 \%$ of the terrestrial soil C, despite comprising a relatively small proportion of the total land area occupied (Amthor and Huston 1998). Current wetland restoration and conservation goals worldwide provide a critical opportunity to incorporate $\mathrm{C}$ sequestration as part of future wetland ecosystem services. Although soil $\mathrm{C}$ in wetland soils has been recognized as being an important component of global $\mathrm{C}$ budgets and future climate change scenarios, very little work has been done on the role of wetland ecosystems management on increasing C sequestration (Amthor and Huston 1998; Lal 2001). Considerable research quantifying $\mathrm{C}$ sequestration rates coupled to ecosystem management scenarios is needed to provide for sound resource management decisions.

Studies on soil accretion in coastal wetland ecosystems have been conducted in wetlands around the world and a wide range of accretion rates have been reported, ranging from 0 to $42 \mathrm{~mm}$ /year (Hatton et al. 1983; Salinas et al. 1986; DeLaune et al. 1990; Twilley et al. 1992; French and Spencer 1993; Parkinson et al. 1994; Chmura et al. 2003; Callaway et al. 1996, 1997; Nyman et al. 2006). Research conducted in the Mississippi River deltaic plain has concluded that organic matter accumulation was the main determinant in the vertical growth rate of marshes (DeLaune et al. 1978, 1994; Hatton et al. 1983; Neubauer 2008). Although there is less soil organic matter in these marshes on a weight basis, the soil organic matter (SOM) occupies considerably greater volume and hence greater importance for accretion of emergent wetlands than mineral matter (Nyman et al. 1990). Organic matter contributes to the soil matrix and increases structural strength by forming an interlocking network of roots. Soil mineral matter may be from $50 \%$ to $90 \%$ of the dry weight of marsh soils, but mineral matter occupies only $2 \%$ to $7 \%$ of soil volume in Mississippi River deltaic plain marshes (Nyman et al. 1990). Stability of the SOM along with the addition of mineral sediments has been recognized as key factors controlling vertical marsh accretion and associated C sequestration (Nyman and DeLaune 1999). 
Large-river delta front estuaries (LDE) such as the Mississippi/Atchafalaya deltas are reported to be important interfaces between continents and oceans. The processes that control the transport and transformation of carbon in LDE are essential to our understanding of carbon sequestration (Bianchi and Allison 2009).

Coastal peat deposits are impacted by a variety of threats associated with global climate change and human land use management (Henman and Poulter 2008). These threats include shoreline erosion (Young 1995), salt water intrusion (Hackney and Yelverton 1990) and submergence (Pearsall and Poulter 2005). All of these factors can reduce $\mathrm{C}$ sequestration. Response of coastal wetlands to climate change factors also include changes in elevation, boundary or edge distribution, areal extent (wetland: water area) and mineral/organic matter composition of soil or sediment (Day et al. 2008). These physical changes strongly impact biological processes including above and below ground plant productivity and $\mathrm{C}$ sequestration.

For the past several thousand years, the development of a mosaic of coastal marshes has been driven by a relatively slow rate of sea-level rise over the latter part of the Holocene. Coastal areas accumulated organic carbon and mineral sediments as marsh vertically accreted at a rate that kept pace with sea-level rise (Redfield 1972; McCaffrey and Thomson 1980; Orson et al. 1985). It has been estimated that saline wetland soils including salt marshes and mangrove swamp store more than 10,000 Tg of C (Twilley et al. 1992; Chmura et al. 2003; Bouillon et al. 2008). There is a great deal of uncertainty about the specific ecological and physical changes that will occur in coastal wetlands as result of increased rates of sea-level rise driven by global climate change.

The resultant increase in sea level associated with global climate change can only be expected to magnify the effect of natural and anthropogenic stress on coastal marshes. There is a wide range of future sea level increases predicted associated with global climate change. Predicted rate of sea level rise (using an empirical approach) in the twenty-first century is reported to be $1 \mathrm{~m}$ or greater (Rahmstorf 2007), which is similar to the present submergence rate of coastal LA. The IPCC prediction based on multiple models and scenarios estimates that sea level at the end of the twentyfirst century will be 28 to $48 \mathrm{~cm}$ above that at the beginning of the century (IPCC 2007). The effects of this increased rate of sea level rise on coastal marshes can range from increasing stress on marsh vegetation to accelerating the rate of marsh loss (Mendelssohn and Morris 2000; Craft et al. 2009).

Currently, LA is experiencing a high relative rate of sea level rise due to eustatic sea level rise coupled with coastal subsidence. (Morton et al. 2010) reported that subsidence rather than erosion was the primary contributor to wetland loss in the Mississippi River deltaic plain. Several studies have shown that accretion in LA coastal marshes is not sufficient to keep pace with water level increases (Cahoon and Reed 1995; Rybczyk and Cahoon 2002). This condition is leading to significant wetland loss due to both the increasing water level and increased salinity (Day et al. 2000). LA subsidence is between five and 10 times the rate of eustatic sea level rise (Callaway et al. 1997; Rahmstorf 2007). Therefore, we can use the wetland responses today in LA to potentially forecast the effects of future projected increases in worldwide sea level on global carbon sequestration and wetland loss. However, it should be noted that in addition to marsh losses from relative sea level rise, other processes including edge erosion to waves, presence of canals, barrier island erosion and impact by large hurricanes have additionally contributed to LA coastal marsh loss. 
Despite the enormous number of studies worldwide on wetland accretion rates, very little analysis has been conducted to determine potential decreases in the $\mathrm{C}$ sequestration potential of coastal wetlands as related to predicted increase in sea level rise. In this paper, we quantified soil carbon sequestration rates (based on existing soil vertical accretion and $\mathrm{C}$ sink data) in LA's rapidly subsiding coastal wetlands. We also calculate the soil $\mathrm{C}$ loss due to deteriorating marshes, including hurricane impacts. In addition, we estimate potential effects of coastal restoration on $\mathrm{C}$ storage in wetland soils. After providing an analysis and synthesis of carbon storage and sequestration determined from vertical soil accretion data for LA's rapidly subsiding coastal wetlands, we have also conducted an analysis based on historical aerial change data for the amount of carbon loss due to marsh deterioration associated primarily with coastal submergence. Wetland area, destroyed by recent hurricanes, as related to carbon storage is also quantified. The amount of carbon storage capacity recovered through restoration or marsh recovery efforts is also presented based on several proposed coastal restoration plans and the potential of carbon credits gained through restoration is determined. While not a focus of this paper, one should be mindful that any process which leads to loss of $\mathrm{C}$ sequestration in marsh soil will also affect the storage of associated nutrients including nitrogen and phosphorus (DeLaune et al. 1989; White and Reddy 2001).

\section{Vertical marsh accretion and soil carbon accumulation in Louisiana gulf coast Marshes}

The LA gulf coast is experiencing a rapid increase in relative water level, primarily as a result of subsidence in the Mississippi River Deltaic plain, in addition to a relatively small rate of eustatic sea level rise $\left(\sim 2 \mathrm{~mm}\right.$ year $\left.^{-1}\right)$. Studies of LA coastal marshes have shown that most marsh areas, for a period of time, can vertically accrete and keep pace with subsidence, although there is overall marsh deterioration (Callaway et al. 1997). Accretion is strongly dependent on organic matter sequestration of significant amounts of C in LA coastal marsh soil profiles (Hatton et al. 1983; DeLaune et al. 1978; Nyman et al. 1990, 1995) and this accretion leads to the sequestration of significant amounts of $\mathrm{C}$ in the marsh profile. The net accumulation of SOM is also affected by the decomposition rate. Soil organic matter is continually oxidized by heterotrophic decomposers, which results in the conversion of organic carbon to $\mathrm{CO}_{2}$ and $\mathrm{CH}_{4}$. Soil organic matter decomposition differs among fresh, brackish, and saline marsh (Smith et al. 1983). Soil organic matter accumulation results from in situ production by marsh plants (autochthonous source), rather than transported into the marsh from other areas (allochthonous source). Therefore, factors which regulate plant productivity will directly affect SOM accumulation. Additionally, well established vegetative communities promote mineral sediment accumulation. Plant stems reduce water velocities, which promotes deposition of mineral matter (Gleason et al. 1979; Rejmanek et al. 1988), and algae on plant stems promotes the trapping of very fine mineral matter, which may otherwise remain suspended in the water column (Stumpf 1983). The amount of OM accumulating in fresh, brackish, and saline marsh soils of the Mississippi River deltaic plain can estimate the amount of SOM production required for marsh maintenance (Nyman et al. 1990). 
Table 1 Annual carbon accumulation rates reported for Louisiana coastal marsh soils

\begin{tabular}{lll}
\hline $\begin{array}{l}\text { Fresh marsh } \\
\mathrm{g} \mathrm{m}^{-2} \text { year }^{-1}\end{array}$ & $\begin{array}{l}\text { Saline marsh } \\
\mathrm{g} \mathrm{m}^{-2} \text { year }^{-1}\end{array}$ & Source \\
\hline 224 & $183-296$ & Smith et al. (1983) \\
$219-298$ & $310-329$ & Hatton et al. (1983) \\
301 & $283-334$ & Nyman et al. (2006) \\
- & $132-227$ & DeLaune and Pezeshki (2003) \\
\hline
\end{tabular}

The role of LA coastal marshes as a $\mathrm{C}$ sink has been demonstrated in a number of studies using the $\mathrm{C}$ and/or OM content and bulk density of the soil as well as the measured vertical accretion rates (Table 1). Accretion rates were calculated from the horizon for 1963, the year of peak ${ }^{137}$ Cs atmospheric fallout (DeLaune et al. 1978). One study found net $\mathrm{C}$ accumulation rate of 183,296 , and $224 \mathrm{~g} \mathrm{C} \mathrm{m}^{-2}$ year $^{-1}$ for Barataria Basin saltwater, brackish, and freshwater marshes, suggesting relatively the same amount of carbon accumulation along a salinity gradient (Smith et al. 1983).

Hatton et al. (1982) and (1983) reported similar C accumulation rates for these marshes. Average OM accumulation rate for marshes were converted where applicable to organic carbon (by multiplying $\mathrm{OM}$ by 0.56 ). The resulting average accumulation rates were $310,329,298$, and $219 \mathrm{~g} \mathrm{C} \mathrm{m}^{-2}$ year $^{-1}$ for salt marsh, brackish, intermediate and freshwater marshes, respectively. DeLaune and Pezeshki (2003) reported organic C accumulation rate of between $132-227 \mathrm{~g} \mathrm{~m}^{-2}$ for a LA brackish marsh. Nyman et al. (2006) reported annual carbon accumulation rate of approximately $300 \mathrm{~g} \mathrm{~m}^{-2}$ for 68 cores taken from 31 fresh and saline marsh sites in coastal LA. These studies demonstrated that the organic matter accumulation rates were similar in the various coastal LA marsh types. The vertical accretion rate ranged from 0.59 to $1.35 \mathrm{~cm} \mathrm{year}^{-1}$ with an average of $\sim 1 \mathrm{~cm} \mathrm{year}^{-1}$. Chmura et al. (2003) who used their own data and published data from the literature for $\mathrm{C}$ accumulation in mangrove swamps and salt marsh suggested globally, marshes sequester $210 \mathrm{~g}$ $\mathrm{C} \mathrm{m}^{-2}$ year $^{-1}$. While it is clear that the rapidly accreting coastal wetlands in LA represent appreciable $\mathrm{C}$ storage in marsh soils, reported $\mathrm{C}$ accumulation rates for coastal LA are somewhat higher than the average for some coastal regions but rates are not unusual. Several coastal systems in the US have $\mathrm{C}$ accumulation rates as high as $300 \mathrm{~g} \mathrm{~m}^{-2}$ year $^{-1}$ (Table 2). Using an average accretion rate of $1 \mathrm{~cm} \mathrm{year}^{-1}$, there is a projected annual $\mathrm{C}$ accumulation of $300 \mathrm{~g} \mathrm{~m}^{-2}$ year $^{-1}$ over a hundred year period leading to $30 \mathrm{~kg} \mathrm{C} \mathrm{m}^{-2}$ accumulated in the marsh soil profile, providing the $\mathrm{C}$ will ultimately be moved into long-term geologic storage rather than exposed through marsh deterioration.

Table 2 Carbon accumulation rates for select coastal regions after Chmura et al. (2003)

\begin{tabular}{llc}
\hline Location & $\begin{array}{c}\text { Carbon storage } \\
\text { rate g C m } \text { year }^{-1}\end{array}$ & Data source \\
\hline San Francisco Bay, CA & $54-385$ & $\begin{array}{c}\text { Patrick and } \\
\text { DeLaune (1990) }\end{array}$ \\
Biloxi Bay, MS & 153 & $\begin{array}{c}\text { Callaway et al. } \\
(1997)\end{array}$ \\
Tijuana Slough, CA & 343 & $\begin{array}{c}\text { Cahoon et al. } \\
(1996)\end{array}$ \\
Chesapeake Bay, MD & $213-340$ & $\begin{array}{c}\text { Kearney and } \\
\text { Stevenson (1991) }\end{array}$ \\
Jacob Creek, NC & $59-146$ & \begin{tabular}{c} 
Craft et al. (1993) \\
\hline
\end{tabular}
\end{tabular}




\section{Effect of wetland loss on carbon storage}

To predict future $\mathrm{C}$ sequestration rates, dynamics of landscape processes must take into account wetland loss due to sea level rise and major hurricane events, which would subtract from net $\mathrm{C}$ storage. Coastal marshes in LA are being converted to open water primarily due to subsidence and associated water level and salinity increases, which negatively impact wetland vegetation. Since the 1930's, it is estimated that 1,900 mile $^{-2}\left(4,920 \mathrm{~km}^{2}\right.$ year $\left.{ }^{-1}\right)$ of land has been lost (Dunbar et al. 1992; Barras et al. 1994, 2003) (Fig. 1). Even though the loss rates have been over $40 \mathrm{mi}^{2}$ year ${ }^{-1}\left(104 \mathrm{~km}^{2}\right.$ year $\left.{ }^{-1}\right)$ primarily from the mid 1950s through the $1970 \mathrm{~s}$, current wetland loss estimates are lower. Between 1990 and 2000 wetland loss rate was estimated to be 24 miles $^{2}$ year ${ }^{-1}\left(62 \mathrm{~km}^{2}\right.$ year $\left.{ }^{-1}\right)$. Recent estimates of land loss by Barras et al. (2008) using regression fits are thought to provide a more reliable loss estimates than comparison of loss based simply on the difference between two single data points. The loss estimate for coastal LA from 1985-2004 was $30.7 \pm$ $5.7 \mathrm{~km}^{2}$ year $^{-1}$ and $39.2 \pm 7.6 \mathrm{~km}^{2}$ for 1985 to 2006 using regression analysis. These loss estimates are lower than the $62 \mathrm{~km}^{2}$ year ${ }^{-1}$ reported by USGS for the time period between 1990 and 2000. Such differences in wetland loss for selected time frames and method used in assessing loss rates should be considered in evaluating $\mathrm{C}$ loss/storage.

\section{₹USGS $100+$ Years of Land Change for Coastal Louisiana}

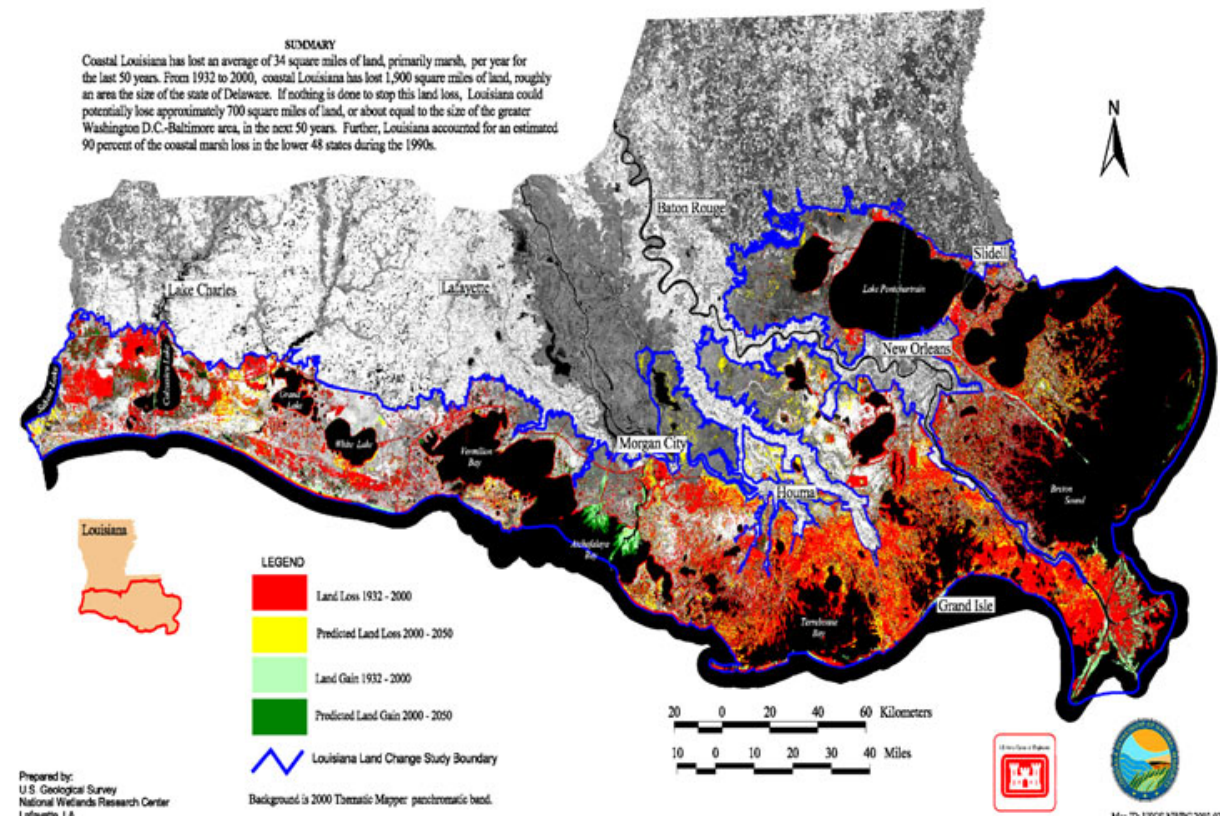

Fig. 1 Historical and projected land loss from coastal Louisiana. Map reproduced from Barras et al. (2003). Historical and projected coastal Louisiana land changes: 1978-2050. USGS Open File Report $03-334,39 \mathrm{p}$ 
For example, even though coastal wetlands in LA are accumulating $\mathrm{C}$ through vertical accretion in response to relative rise in water levels, these wetlands are also losing soil $\mathrm{C}$ through marsh deterioration. Much of the wetland loss occurring in coastal LA is due to the deterioration of the highly organic marsh soil. Conversion of coastal marshes to inland open water is driven by plant stressors such as salinity changes driven by saltwater intrusion into non-saline marshes and increased soil water-logging as a result of subsidence. The marsh soil elevation decreases rapidly following plant morality because of the structural collapse of the living root network (DeLaune et al. 1994). The peat collapse and the associated erosion result in the conversion of marsh to ponds or open water of $\sim 1 \mathrm{~m}$ in depth. Following storm surge inundation in coastal North Carolina, collapse of freshwater peat was also observed after vegetation die off, similar to the observed phenomenon in LA (Cahoon et al. 2003).

For thousands of years, coastal ecosystems migrated landward in face of rising sea level during the Holocene (Parkinson and White 1993). Due to restrictions such as storm protection levees and human development, there is little area for upland migration of coastal marshes in response to sea level rise in most coastal areas worldwide. As a result, most coastal marshes are being replaced by shallow open water area as sea level continues to rise. Conversions of marshes to open water releases a considerable amount of $\mathrm{C}$ into the adjacent estuary, where it is either decomposed to $\mathrm{CO}_{2}$, accumulated in bottom sediment of estuary, or exported to the coastal shelf ( $\mathrm{Li}$ et al. 2009a, 2011). Field studies in coastal North Carolina have shown that higher rates of erosion can contribute to large $\mathrm{C}$ fluxes to estuaries (Young 1995). For LA, we estimate that the majority of the organic matter loss through marsh deterioration would be exported to estuaries or offshore areas, with a significant portion of the organic matter oxidized in the process. Sampere et al. (2008) using lignin and pigment markers of organic matter in surface sediment of the LA continental margin following Hurricane Ivan, indicated that organic inputs from bays and coastal wetlands were likely rapidly decomposed. Another study found that a majority of the organic matter in coastal bay sediment was from phytoplankton as opposed to salt marsh plants suggesting much of the $\mathrm{C}$ lost from marshes was oxidized instead of preserved by burial (DeLaune and Lindau 1987). The C content of inner shelf sediments off the coast of the Atchafalaya River, LA averages $1.17 \%$ suggesting low C preservation on the shelf (White et al. 2009a).

The majority of the soil loss is organic with a concomitant amount of soil organic carbon. If we assume that a $100 \mathrm{~cm}$ depth of organic soil is lost over time due to marsh loss, this would be equivalent to $30 \mathrm{~kg} \mathrm{C} \mathrm{m}^{-2}$ or 300 metric tons ha ${ }^{-1}$, or 30,000 metric tons $\mathrm{km}^{-2}$. Table 3 lists the amount of carbon loss based on several estimates of wetland loss and total amount of carbon loss since the 1930s for coastal LA. Based on reported rates of marsh loss $\left(\sim 62 \mathrm{~km}^{2}\right.$ year $\left.{ }^{-1}\right)$, it is estimated that $1.86 \times 10^{6}$ metric tons $\mathrm{C}$ year ${ }^{-1}$ is lost. If we use $30.7 \pm 5.7$ reported by

Table 3 Carbon losses through marsh deterioration

\begin{tabular}{|c|c|}
\hline Rate of marsh loss $\left(\mathrm{km}^{2}\right.$ year $\left.^{-1}\right)$ & $\begin{array}{l}\text { Soil carbon loss } \\
\left(\times 10^{6} \text { metric tons year }^{-1}\right)\end{array}$ \\
\hline 62 (current) & 1.86 \\
\hline 104 (average loss 50s through 70s) & 3.12 \\
\hline 4,920 (total since 1930$)$ & 147.6 \\
\hline
\end{tabular}




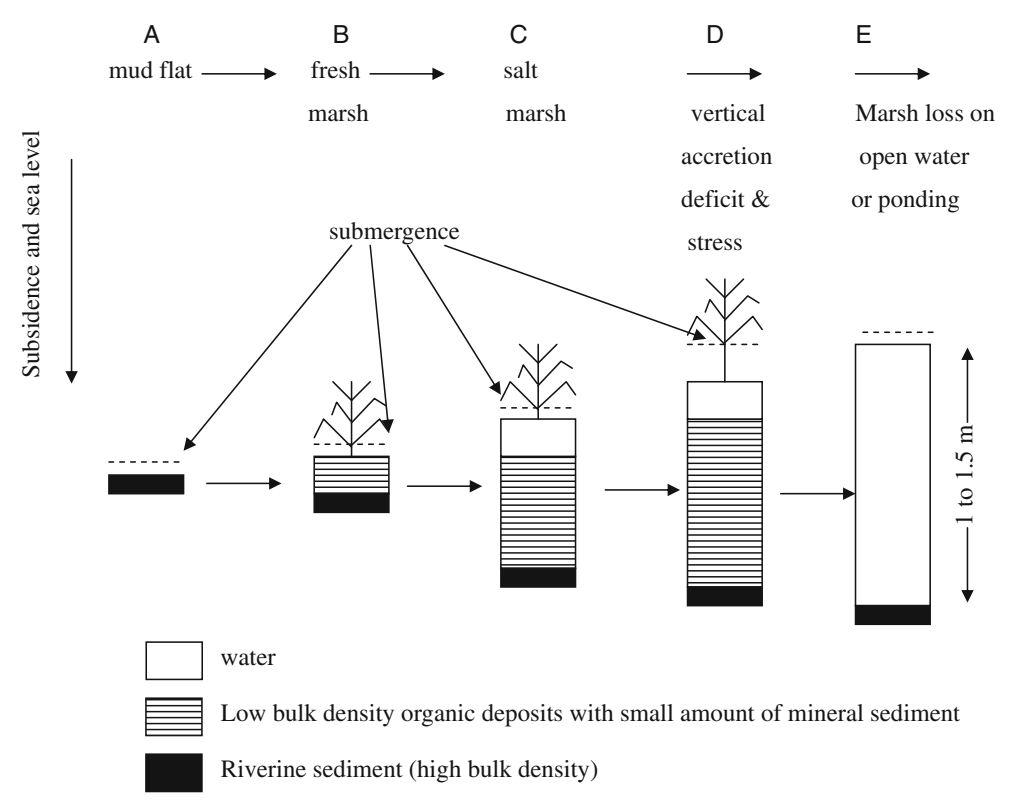

Fig. 2 Schematic of processes involved in marsh formation and loss as related to organic soil accumulation and loss

Barras et al. (2008), the loss is $\sim 0.92 \pm 0.6 \times 10^{6}$ metric tons $\mathrm{C}$ year ${ }^{-1}$ lost. Based on $104 \mathrm{~km}^{2}$ year $^{-1}$ for the 1950 s through 1970 s estimate of wetland loss, the carbon loss over that period was $3.12 \times 10^{6}$ metric tons year $^{-1}$. Total carbon loss since the 1930 s associated with total area of marsh deterioration since this period is equivalent to $147.6 \times 10^{6}$ metric tons and this estimate does not include the loss of the potential future sequestration of marsh. We would like to stress that estimated carbon loss is dependent on the particular time frame and method used in determining wetland loss.

This above estimate is also conservative based on the peat depth estimate. Wilson and Allison (2008) estimated that depth of an eroded marsh in southeast LA marsh is approximately $150 \mathrm{~cm}$. Therefore, for marshes with more extensive peat deposits, there would be a larger amount of $\mathrm{C}$ lost. The actual amount for any particular location will vary depending on a number of soil physiochemical properties including bulk density, organic soil depth, and soil organic carbon content. A depiction of the vertical loss of $\mathrm{C}$ is illustrated in Fig. 2. Based on this comparison, a coast wide wetland loss of more than one percent of total marsh area per year will result in a net loss of $\mathrm{C}$ storage by marsh soils because of the depth of the $\mathrm{C}$ exhumed by physical processes. Therefore, it is critical to determine $\mathrm{C}$ sequestration losses not simply on an areal basis but also include a depth estimate.

\section{Hurricane effects on marsh loss and carbon storage}

Coastal wetland loss has episodically been impacted by severe storm events. Resulting storm surge from hurricanes can scour and redeposit rooted marsh vegetation. 
Salt water, pushed inland by storm surge and tide ( $\mathrm{Li}$ et al. 2009b), can also negatively affect marsh vegetation communities. There is evidence that climate change will result in increased storm frequency and intensity. It has been reported that sea surface temperatures in the tropics has increased by $1^{\circ} \mathrm{C}$ over the past century and over this period hurricane intensity has also increased (Emanual 2005). Hoyos et al. (2006) reported the increase in number of category 4 and 5 hurricanes for the period 1970-2004 was linked to the increase in surface water temperature. If the above scenario continues, all coastal marshes can expect to be impacted by major hurricanes on a more frequent basis in the future. Such an increase would likely have an impact on soil C storage in northern Gulf of Mexico marshes due to the low-lying coastal topography.

For coastal LA, it has been estimated that the combined effect of recent (2005) hurricanes, Katrina and Rita resulted in a loss of over 200 miles $^{2}\left(520 \mathrm{~km}^{2}\right)$ of coastal marsh (Barras 2006; Howes et al. 2010). This loss is approximately equivalent to $15.4 \times 10^{6}$ metric tons $\mathrm{C}$ to a depth of $100 \mathrm{~cm}$. The estimated loss from both 2005 hurricanes would equal $76 \%$ of the $743 \mathrm{~km}^{2}$ of wetland area loss occurring between the periods of 1978 and 2004 (Barras et al. 2008). For example, the net coastal marsh area loss from 2001 to 2004 (3 years period) prior to the 2005 hurricanes was $49.2 \mathrm{~km}^{2}$. Losses for the period from 2004 to 2006 (following hurricanes) were one order of magnitude greater at $513 \mathrm{~km}^{2}$ (Barras et al. 2008). The large-scale losses observed after the 2005 hurricanes implies that past extremes hurricanes, greater the Category 2 have likely significantly contributed to the $2,238 \mathrm{~km}^{2}$ of net loss that has occurred within coastal LA between 1956 and 1978. The 1978 to 2004 period, used for current land loss projections (Barras et al. 2003) was characterized by primarily low-intensity hurricane landfalls in LA. However, nearly instantaneous land loss from Hurricanes Katrina and Rita in 2005 and Gustav and Ike in 2008 (Gustav and Ike resulted in $320 \mathrm{~km}^{2}$ of coastal land loss) was equivalent to almost two and a half decades of prior coastal land loss (from 1978 through 2004) underscoring that major hurricanes are a significant contributor to coastal land loss (Barras 2009).

We would like to caution, this estimate is not directly related to net $\mathrm{C}$ loss due to the fact these recent hurricanes can scour the marsh and redeposit some of the $\mathrm{C}$ on the surface of the adjacent marsh. Although hurricanes can damage or destroy the wetlands, they can also benefit marshes by delivering sediment and organic material that can raise the marsh elevation in some areas while reducing it in other. McKee and Cherry (2009) reported that Hurricane Katrina added 1 to $8 \mathrm{~cm}$ of sediment to the soil surface of two brackish marshes in the path of the hurricane. However, due to subsequent oxidation and/or subsidence, the net elevation gain two years after the hurricane was only 1.7 and $+0.7 \mathrm{~cm}$

In addition the spatial depiction of land area change represents a complex and interwoven mosaic of loss and gain patterns caused both by natural and human induced forces operating at various temporal and spatial scales resulting in fluctuating contributions to coastal land loss (Barras 2009). For example, recent land losses caused by hurricanes can comingle with prior estimates of land losses. Extreme storm such as Katrina and Rita can alter the long term time-average trend of coastal land loss. This change in rate of land loss pattern with time can also influence $\mathrm{C}$ storage. 


\section{Influence of coastal restoration on carbon storage}

Coastal restoration projects are designed to reduce the rate of marsh loss, and this must also be factored into a landscape budget of $\mathrm{C}$ sequestration. The value of $\mathrm{C}$ sequestration of marshes should be factored into a cost/benefits analysis of coastal restoration options relative to no-action in slowing land loss in the coastal zone. The Coast 2050 plan (1998) represent strategies and specific objectives for restoring LA's rapidly deteriorating coastal wetland. The Coast 2050 Plan was developed in partnership with the public, parish governments, State and Federal agencies and is based on technically sound strategies designed to sustain coastal resources. The plan is an overall template which will provide program-neutral guidance for the development and implementation of coastal restoration projects.

We have calculated the projected area of marsh which would be conserved by 2050 by the proposed restoration plan, which includes diverting Mississippi River water into LA coastal wetlands (Table 4). The introduction of nutrient-laden river water can significantly increase plant productivity and burial of soil carbon. Based on the acreage of marsh conserved, we estimated the amount of $\mathrm{C}$ storage equivalence (Table 4). These reported estimates are for fully restored marshes. River diversions will also decrease marsh salinity leading to less stress on the coastal vegetation and will likely slow the rate of wetland loss while also removing Mississippi River nitrate (White et al. 2009b; Gardner and White 2010). The actual amount of marsh conserved by coastal restoration is difficult to estimate. One estimate (Barras et al. 2003) projected $500 \mathrm{mi}^{2}\left(1,275 \mathrm{~km}^{2}\right)$ or $10 \mathrm{mi}^{2}$ year ${ }^{-1}$ of marsh preserved over the next 50 years based on current restoration efforts. The above estimate (Barras et al. 2003; Coast 1998) were pre-hurricanes Katrina and Rita in 2005 and Gustav and Ike in 2008. Though difficult to quantify at this early point in the restoration time-line, these measures will influence $\mathrm{C}$ storage.

Visser et al. (2008), using the CLEAR Landscape Change model (www.clear. lsu.edu) provides a higher estimate of wetland area gained through planned restoration efforts. Over the course of a 50-year simulation (assuming historical land loss rate remained the same), the restoration scenario resulted in an overall wetland loss

Table 4 Wetland area in coastal Louisiana showing hectares of marsh preserved

\begin{tabular}{llcccc}
\hline Region & Basin & $\begin{array}{l}\text { Hectare of } \\
\text { Marsh in 1990 }\end{array}$ & $\begin{array}{l}\text { Hectare of } \\
\text { Marsh lost } \\
\text { by 2050 without } \\
\text { restoration }\end{array}$ & $\begin{array}{l}\text { Estimated } \\
\text { hectare of } \\
\text { marsh } \\
\text { preserved }\end{array}$ & $\begin{array}{l}\text { Estimated } \\
\text { carbon } \\
\text { stored/preserved } \\
\left.\text { (metric ton C } \times 10^{6}\right)\end{array}$ \\
\hline 1 & Pontchartrain & 102,465 & 20,384 & 1,912 & 0.574 \\
2 & Breton Sound & 69,296 & 18,014 & 7,250 & 2.175 \\
2 & Mississippi Delta & 25,961 & 10,016 & 7,428 & 2.228 \\
2 & Barataria & 171,518 & 54,671 & 17,180 & 0.515 \\
3 & Terrebonne & 197,964 & 58,826 & 2,094 & 0.628 \\
3 & Atchafalaya & 19,764 & $12,162^{\mathrm{a}}$ & 3,272 & - \\
3 & Teche/Vermilion & 94,892 & 13,025 & 1,361 & 0.408 \\
4 & Mermentau & 178,605 & 24,993 & 1,053 & 0.316 \\
4 & Calcasieu/Sabine & 128,426 & 20,590 & 5,038 & 1.511 \\
& Total & 988,889 & 208,356 & 46,587 & 13.676 \\
\hline
\end{tabular}

Source: Coast 2050, through restoration (e.g. river diversion) and estimated carbon storage

${ }^{a}$ Due to delta building, land will be gained in the Atchafalaya Basin 
of $619 \mathrm{~km}^{2}$ (5\% of current wetland area), while $2,368 \mathrm{~km}^{2}$ (18\% of current wetland area) of wetlands were simulated as being converted to open water under the no action scenario. According to the CLEAR Landscape Change module output, the current restoration scenario prevents the loss of $1,749 \mathrm{~km}^{2}$ of wetland over a 50 -year span $\left(35 \mathrm{~km}^{2}\right.$ year $\left.^{-1}\right)$ across the coast of LA when compared to the same time frame given the no action scenario. This translates into a $13 \%$ reduction in total wetland area loss over the course of 50 years with significant associated $\mathrm{C}$ storages.

The amount and temporal dynamics of wetland area created by Mississippi River water diversions versus wetland area created by direct wetland and barrier island creation projects was also included in this estimate. After 50 years of continual restoration efforts, $598 \mathrm{~km}^{2}$ of wetlands are predicted to be created by river diversion processes and $540 \mathrm{~km}^{2}$ will be created by marsh and barrier island construction projects. It should be noted that barrier island restoration would not have same $\mathrm{C}$ sequestration rate as fresh and brackish marsh but may play a role in protecting vulnerable coastal wetlands. Wetland creation from Mississippi River diversions is a gradual and steady process over time, whereas wetland created from marsh/barrier island creation projects is an 'instant' addition of wetland area/protection.

All of the restoration scenarios (Coast 1998; Visser et al. 2008) are best case scenario estimates. The success of coastal restoration is also contingent on funding for completing and maintaining the numerous restoration projects. This examination, however, does show that restoration is critically important for slowing the rate of wetland loss concomitantly maintaining $\mathrm{C}$ sequestration in LA's subsiding coastal environment. It is also clear from this estimate that not all of the coastal marsh can be preserved or restored. Losses will continue, albeit at a slower, more gradual rate.

To restore carbon loss as result of wetland deterioration is difficult. Once marshes are converted to open water, vegetation cannot easily re-establish. In order for vegetation to be re-established, the open bays and water bodies would have to be filled with sufficient mineral sediment to provide a substrate for vegetation to become established (see Fig. 2). Part of the problem is that the Mississippi and Atchafalaya rivers currently carry about $1 / 2$ the sediment load they did a century ago, an annual amount of 205 million metric tons (Blum and Roberts 2009). Dams and reservoirs built on rivers and streams that feed the Mississippi River now captures a significant amount of the historical sediment load. In order to fill in open water areas, diversion or other activities (dredging) would need to be delivered to a depth that would support emergent marsh vegetation. The amount of sediment for filling in $1 \mathrm{~m}$ depth of a open water area (assuming bulk density of between 0.7 and $1.0 \mathrm{~cm}^{3}$ ) would be equivalent to between 700 and $1,000 \mathrm{~kg}$ sediment $\mathrm{m}^{-2}$ or between 0.7 to 1.0 metric ton $\mathrm{m}^{-2}$, The amount of sediment required over a $1 \mathrm{~km}^{2}$ area would be between 0.7 to $1.0 \times 10^{6}$ metric tons.

Based on a wetland loss rate of $61.2 \mathrm{~km}^{2}$ year $^{-1}$ and if we assume one million metric tons of sediment required to restore $1 \mathrm{~km}^{2}$ of open water area, $\sim 61$ million metric tons of sediment would be required to restore a $61 \mathrm{~km}^{2}$ area of wetlands. This is an amount equivalent to a $1 / 3$ of the total sediment load of the Mississippi River today. To restore the over $4,000 \mathrm{~km}^{2}$ area of wetland area lost since the 1930 , assuming a minimum depth of $1 \mathrm{~m}$, would require re-depositing several decades worth of supply of Mississippi River sediment, an amount which is currently not available (Blum and Roberts 2009). Such a restoration would also require diverting the sediment load to the areas where loss occurred. It is highly improbable that this could be done due to cost and difficulties of implementation. 
Future projected losses of coastal wetland area are not simply a Louisiana problem. Craft et al. (2009), in a study of the Georgia coastal area using simulation modeling and the IPCC mean and maximum estimate of sea level rise for the year 2100 , reported that salt marsh area will decrease by $20 \%$ and $45 \%$ respectively. The tidal freshwater marsh was predicted to increase by $2 \%$ under IPPC mean scenario but would decline by $39 \%$ under the maximum scenario. Such declines in marsh area will also likely result in loss of $\mathrm{C}$ storage for coastal areas world-wide, the effects of which are seen today in LA.

\section{Monetary value of wetland soil carbon}

While it may be difficult to put a monetary value on all the benefits of coastal restoration, the concept of $\mathrm{C}$ credits is a new concept which can provide value to restoration efforts. Under the Marrakech Accords, soil $\mathrm{C}$ can be included in the calculation of $\mathrm{C}$ sinks for the first commitment period of the Kyoto Protocol. Because $\mathrm{C}$ sequestration can be used to offset industrial $\mathrm{C}$ emissions through the Kyoto Protocol, soil $\mathrm{C}$ is now a commodity that can be bought and sold (Sandor and Skees 1999; Lal 2004). The Chicago Climate Exchange (CCX) is the first legally binding, rule-based program that allows corporations, non-government organizations, cities, and farmers to trade on the release and capture of $\mathrm{CO}_{2}$ and other greenhouse gases (Lal 2004). The ability to sell C credits offers a powerful incentive for coastal landowners to actively participate in coastal wetlands preservation and restoration. Carbon credits prices vary widely. US voluntary market price range from US $\$ 1.00$ to US\$10.00 per credit. A credit is equal to 1 metric ton of $\mathrm{C}$ dioxide or greenhouse gas equivalent. To convert a ton of soil $\mathrm{C}$ to carbon dioxide equivalent we have to multiply by 3.66 since $\mathrm{CO}_{2}$ is only $27.3 \% \mathrm{C}$. For example if the market value in the CCX is US\$3.00 per metric ton of $\mathrm{CO}_{2}$ we would multiply $3 \times 3.66$ to covert to $\mathrm{C}$ equivalent or US\$11.00 per ton of soil C.

For coastal LA, we can now estimate the value of the $\mathrm{C}$ sequestered in coastal marshes. We know that the equivalent of 3 metric tons $\mathrm{C} \mathrm{ha}^{-1}$ is sequestrated on an annual basis using $300 \mathrm{~g}$ organic carbon per square meter accumulating annually in the marsh soil at an average accretion rate of $1 \mathrm{~cm}$ year ${ }^{-1}$. Louisiana has a total of 988,888 ha of marsh (Coast 1998). Therefore, the equivalent of 2.9 million metric ton of $\mathrm{C}$ would be sequestrated annually in LA coastal marsh through vertical accretion. At a potential value of between $\$ 30$ and $\$ 45 /$ ha, the total value of the $\mathrm{C}$ sequestered in the La coastal region can then be calculated assuming the current $\mathrm{C}$ credit price per ton of US $\$ 10.00-15.00$. For the 988,888 ha of coastal wetland in LA, this C would be worth between 29.7 and 44.5 million dollars each year.

\begin{tabular}{lll}
\hline Louisiana Marsh sequestration & Carbon credit per ton & Hectare value \\
3 metric tons $C \mathrm{ha}^{-1}$ & US\$10-15/ton & $\$ 30-\$ 45 \mathrm{C}$ credit ha \\
\hline
\end{tabular}

988,888 total ha $* \$ 30-\$ 45$ carbon credit $\mathrm{ha}^{-1}=\mathrm{US} \$ 29.7-44.5$ million.

However, this value does not factor in the amount or area of annual wetland loss, again assuming the amount of $\mathrm{C}$ to $100 \mathrm{~cm}$ depth. Using the US\$10-15 C credit equivalent values per metric ton, this loss would be between US\$3,000 and US $\$ 4,500 \mathrm{ha}^{-1}$, assuming that all of the $\mathrm{C}$ was lost from the system. If we calculate 
the annual loss through marsh deteriorating over the entire coast, which is $1.86 \times$ $10^{6}$ metric ton/year and using the US\$10-15/ton, the equivalent of between US\$18.6 and 27.9 million is lost through marsh deterioration each year. This disproportionate loss is due to the erosion of the vertical peat profile once the marsh is converted to open water. Although both DeLaune and Lindau (1987) and Young (1995) have found little of the translocated organic matter preserved in estuarine sediments, we can still use a more conservative estimate for $\mathrm{C}$ loss from the system. Assuming only one half of the $\mathrm{C}$ is lost from the system while the remainder of the $\mathrm{C}$ is re-buried in estuarine or shelf sediments, a loss of approximately $0.93 \times 10^{6}$ metric tons of $\mathrm{C}$ would still be realized.

Episodic, severe storm events, which occur several times a century, can also affect the $\mathrm{C}$ storage as previously documented. Based on the marsh loss $\left(520 \mathrm{~km}^{2}\right)$ from hurricanes Rita and Katrina, an equivalent of $15.4 \times 10^{6}$ metric tons of $\mathrm{C}$ was lost. This value equates to US\$154-231 million, based on US\$10-15 value per metric ton and should be considered in the calculation of the monetary storm damage. Similar but small losses would have been associated with Gustav and Ike in which $320 \mathrm{~km}^{2}$ of wetland loss occurred. The net loss of $\mathrm{C}$ from hurricane events may be less than this estimate if primary productivity increased in short-term from the disturbance. More research is needed to more accurately estimate the permanent net $\mathrm{C}$ loss from storm events.

When we place coastal restoration efforts in the context of $\mathrm{C}$ credit, ongoing coastal restoration effort (e.g., river diversion) can potentially reduce this rate of loss. For example, a $10 \%$ reduction in the loss of marsh would result in reduction of $0.098 \times 10^{6}$ metric tons $\mathrm{C}$ loss annually, which is equivalent to US\$0.98 to 1.47 million per year. This analysis provides a context to predict the monetary value of $\mathrm{C}$ storage in coastal wetlands and could potentially stimulate greater public support for coastal restoration efforts. Realizing the monetary value of wetland $\mathrm{C}$ accumulation may be an important mechanism for providing funding for coastal restoration projects. Individuals or companies may provide financial backing restoration projects that would provide a net sequestration of $\mathrm{C}$ as a means for investment due to the increasing focus on carbon credit value.

\section{Conclusion}

Carbon storage or loss in coastal wetland are related to several factors including sea level rise, accumulation rate, boundary conditions (development barriers such as protection levee that prevent the inland migration of wetlands), subsidence, storm events, rate of wetland loss and coastal restoration. We have estimated the major factors governing $\mathrm{C}$ sequestration and/or loss of C storage in LA's coastal marshes (Fig. 3).

The annual amount of $\mathrm{C}$ sequestered in soil profile by vertical accretion in coastal LA is $2.96 \times 10^{6}$ metric tons C. By comparison current annual loss via marsh deterioration is $1.86 \times 10^{6}$ metric tons or approximately $63 \%$ of the $\mathrm{C}$ sequestered through vertical marsh accretion. Total carbon loss associated with marsh loss since the 1930 s is $147.6 \times 10^{6}$ metric tons. Major hurricane such as Rita and Katrina in 2005 contributed to an estimated C loss of $15.4 \times 10^{6}$ metric ton. The losses associated with marsh deterioration and hurricanes are conservative since it is based on a $1 \mathrm{~m}$ peat 


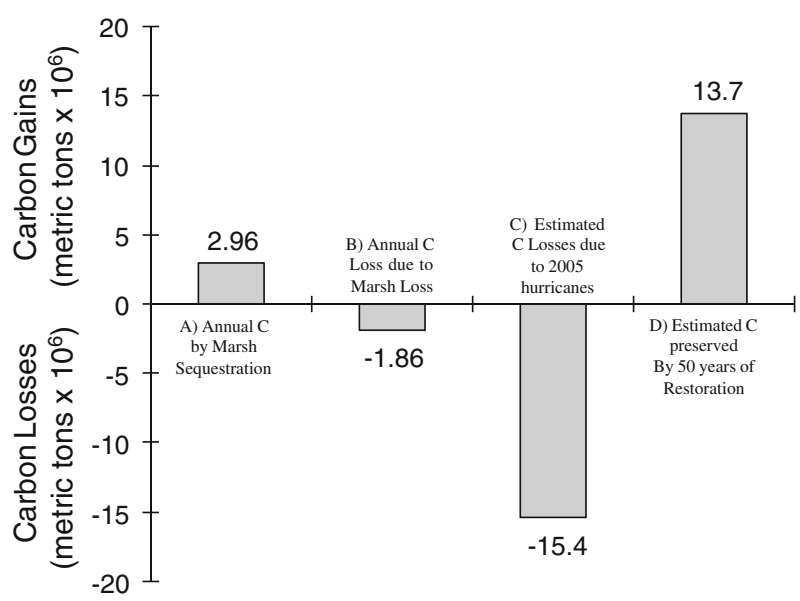

Fig. 3 Estimated gains and losses of carbon (C) from a number of processes in the coastal zone. $A$ Annual $\mathrm{C}$ sequestered through vertical accumulation, $2.96 \times 10^{6}$ metric tons, $B$ Annual $\mathrm{C}$ loss through marsh deterioration (based on current loss of $62 \mathrm{~km}^{2}$ year ${ }^{-1}$ ) $1.86 \times 10^{6}$ metric tons, $C$ Hurricane loss (Katrina and Rita), $15.4 \times 10^{6}$ metric tons, $D$ Estimated amount of C preserved by 2050 proposed coastal restoration (Coast 1998) efforts which include river diversions $(13.67 \times$ $10^{6}$ metric tons)

depth. If the average depth lost depth greater, than greater $\mathrm{C}$ loss would be realized. It has been estimated that hurricanes of the intensity of Katrina and Rita occur once in a 50-100 years time period. Regardless, the values estimated herein demonstrate that hurricanes can significantly impact $\mathrm{C}$ sequestration in coastal wetlands. The loss of $\mathrm{C}$ from these two major hurricanes is on the same order of magnitude as the estimated amount of $\mathrm{C}$ preserved over the next 50 years of coastal restoration efforts as restoration strategies (Coast 1998) are estimated to prevent $13.67 \times 10^{6}$ metric tons of $\mathrm{C}$ from being lost over 50 years and this value compares with the 2005 hurricane losses estimate of $15.4 \times 10^{6}$ metric tons of C.

These calculations provide significant insight on the relative importance of a number of impacts to coastal marshes including coastal submergence, hurricane induced wetland loss, and coastal restoration on C storage including potential $\mathrm{C}$ credit value. Additional studies and model refinement will be needed to provide more accurate estimates, but the data presented herein provides a general estimate of the factors impacting carbon storage and losses in the rapidly subsiding Mississippi River deltaic plain. It has been shown that on a local scale, marshes may serve as a net carbon sink, but based on a total coastal area basis, there may have been an overall net loss of $\mathrm{C}$ over the past century. Because of the high relative rate of sea level rise currently being experienced in LA, these results can be, to a degree, extrapolated for other coastal wetland areas world-wide that will be impacted by future projected sea level rise as the global eustatic sea level rise continues to increase due to climate change.

Open Access This article is distributed under the terms of the Creative Commons Attribution Noncommercial License which permits any noncommercial use, distribution, and reproduction in any medium, provided the original author(s) and source are credited. 


\section{References}

Amthor JS, Huston MA (1998) Terrestrial ecosystem response to global change: a research strategy. Oak Ridge National Laboratory, Oak Ridge, Report ORNL/TM-1998/27

Armentano TV, Menges ES (1986) Patterns of change in the carbon balance of organic soil-wetlands of the temperate zone. J Ecol 74:755-774

Barras JA (2006) Land area change in coastal Louisiana after the 2005 hurricane. A series of three maps: USGS Open-File Report 06-1274

Barras JA (2009) Land area change and overview of major hurricane impacts in coastal Louisiana, 2004-08: USGS Scientific Investigations Map 3080, scale 1:125,000, 6 p

Barras JA, Bernier JC, Morton RA (2008) Land loss change in coastal Louisiana: a multidecadal perspective (from 1956 to 2006): USGS Survey Scientific Investigations Map 3019, scale 1:2,500,000. 14 p. pamphlet

Barras J, Beville S, Britsch D, Hartley S, Hawes S, Johnston J et al (2003) Historical and projected coastal Louisiana land changes: 1978-2050. USGS Open File Report 03-334, pp 39

Barras JA, Bourgeois PE, Handley LR (1994) Land loss in coastal Louisiana 1956-90. National Biological Survey, National Wetlands Research Center Open File Report 94-01.1

Bianchi TS, Allison MA (2009) Large-river delta-front Estuaries as natural "recorders" of global environmental change. Proc Natl Acad Sci U S A 106:8085-8092

Blum MD, Roberts HH (2009) Drowning of the Mississippi Delta due to insufficient sediment supply and global sea-level rise. Nat Geosci 2:488-491

Bouillon S, Borges AV, Castañeda-Moya E, Diele K, Dittmar T, Duke NC et al (2008) Mangrove production and carbon sinks: a revision of global budget estimates. Glob Biogeochem Cycles 22:GB2013. doi:10.1029/2007GB003052

Bridgham SD, Megonigal JP, Keller JK, Bliss NB, Trettin C (2006) The carbon balance of North American wetlands. Wetlands 26:889-916

Cahoon D, Reed D (1995) Relationship among marsh surface topography, hydroperiod and soil accretion in deteriorating Louisiana salt marsh. J Coast Res 11:357-369

Cahoon DR, Lynch JC, Powell A (1996) Marsh vertical accretion in a southern California estuary, USA. Estuar Coast Shelf Sci 43:19-32

Cahoon DR, Philippe H, John R, McKee KR, Profitt C, Perez BC (2003) Mass tree mortality leads to mangrove peat collapse at bay Islands, Honduras after Hurricane Mitch. J Ecol 91:1093-1105

Callaway JC, DeLaune RD, Patrick WH Jr (1996) Sediment accretion in coastal wetlands: a review and a stimulation of processes. Curr Top Wetl Biogeochem 3:2-23

Callaway JC, DeLaune RD, Patrick WH Jr (1997) Sediment accretion rates from four coastal wetlands along the Gulf of Mexico. J Coast Res 13 181-191

Chmura GL, Anisfeld SC, Cahoon DR, Lynch JC (2003) Global carbon sequestration in tidal, saline wetland soils. Glob Biogeochem Cycles 17:1111. doi:10.1029/2002GB001917

Choi Y, Wang Y (2004) Dynamics of carbon sequestration in a coastal wetland using radiocarbon measurements. Glob Biogeochem Cycles 18:4016. doi:10.1029/2004GB002261

Coast 2050 Plan (1998) Louisiana Coastal Wetlands Conservation and Restoration Task Force and the Wetland Conservation and Restoration Authority. Toward a Sustainable Coastal Louisiana. LA Dept of Natural Resources. Baton Rouge, pp 161

Craft C, Clough J, Ehman J, Joye S, Park R, Pennings S et al (2009) Forecasting the effects of accelerated sea level rise on tidal marsh ecosystems services. Front Ecol Environ 7:3-78

Craft CB, Seneca ED, Broome SW (1993) Vertical accretion in microtidal regularly and irregularly flooded estuarine marshes. Estuar Coast Shelf Sci 37:371-386

Day JN, Christian RR, Boesch DM, Yanez-Arancibia A, Morris J, Twiley RR et al (2008) Consequences of climate change on the ecogeomorphology of coastal wetlands. Estuar Coast 31:477491

Day J, Shaffer G, Britsch L, Reed D, Hawes S, Cahoon D (2000) Pattern and process of land loss in the Mississippi delta: a spatial and temporal analysis of wetland habitat change. Estuaries 23:425-438

DeLaune RD, Lindau CW (1987) $\delta^{13}$ C Signature of organic carbon in estuarine bottom sediment as an indicator of carbon export from adjacent marshes. Biogeochemistry 4:225-230

DeLaune RD, Pezeshki SR (2003) The role of soil organic carbon in maintaining surface elevation in rapidly subsiding US Gulf of Mexico coastal marshes. Water Air Soil Pollut 3:167-179 
DeLaune RD, Buresh RJ, Patrick WH Jr (1978) Sedimentation rates determined by ${ }^{137}$ Cs dating in a rapidly accreting salt marsh. Nature 275:532-533

DeLaune RD, Feijtel TC, Patrick WH Jr (1989) Nitrogen flows in Louisiana Gulf Coast salt marsh: Spatial Considerations. Biogeochemistry 8:25-37

DeLaune RD, Nyman JA, Patrick WH Jr (1994) Peat collapse, ponding, and wetland loss in a rapidly submerging coastal marsh. J Coast Res 10:1021-1030

DeLaune RD, Pezeshki SR, Pardue JH, Whitcomb JH, Patrick WH Jr (1990) Some influences of sediment addition to deteriorating salt marsh in the Mississippi River deltaic plain: a pilot study. J Coast Res 6:181-188

Dunbar JB, Britsch L, Kemp E (1992) Land loss rates: Louisiana Coastal Plain. Technical Report GL-92-3, USACE Waterways Experiment Station, Vicksburg, MS

Emanual K (2005) Increasing destruction of tropical cyclones over the last 30 years. Nature 436:686

Erwin KL (2009) Wetlands and global climate change: the role of wetland restoration in a changing world. Wetlands Ecol Manag 17:71-84

Eswaran H, van der Berg E, Reich P, Kimble J (1995) Global soil carbon resources. In: Lal R, et al (eds) Soil and global change. CRC, Boca Raton

French JR, Spencer T (1993) Dynamics of sedimentation in a tide-dominated backbarrier salt marsh, Norfolk, UK. Mar Geol 110:315-331

Gardner LM, White JR (2010) Denitrification enzyme activity as a potential spatial indicator of nitrate loading in a Mississippi River diversion wetland. Soil Sci Soc Am J 74:1037-1047

Gleason ML, Elmer DA, Pien NC, Fisher JS (1979) Effect of stem density upon sediment retention by salt marsh cord grass Spartina patens Loisel. Estuaries 2:271-273

Hackney C, Yelverton G (1990) Effect of human activities and sea level rise on wetland ecosystems in the Cape Fear River Estuary, Northern Carolina, USA. Kluwer, Dordecht

Hatton RS, DeLaune RD, Patrick WH Jr (1983) Sedimentation, accretion, and subsidence in marshes of Barataria Basin. Louisiana. Limnol Oceanogr 28:494-502

Hatton RS, Patrick WH Jr, DeLaune RD (1982) Sedimentation, nutrient accumulation and early digenesis in Louisiana Barataria Basin coastal marshes. 6th Biennial Estuarine Res. Fed. Meet. Estuarine Comparison. Academic Research. pp 255-267

Henman J, Poulter B (2008) Inundation of freshwater peatlands by sea level rise: uncertainty and potential carbon cycle feedbacks. J Geophys Res Biogeosci 13:G01011. doi:10.1029/2006JG000395

Howes NC, FitzGerald DM, Hughes ZJ, Georgiou IY, Kulp MA, Miner MD, Smith JM, Barras JA (2010) Hurricane-induced failure of low salinity wetlands. Proc Natl Acad Sci 107:14014-14019

Hoyos C, Agudelo P, Webster P, Curry J (2006) Deconvolution of the factors contributing to the increase in global hurricane intensity. Science 312:94-97

IPCC (International Government Panel on Climate Change) (2007) Climate change (2007). The Science Basis, Contribution of Working Group 1 to the Fourth Assessment Report. Cambridge University Press, Cambridge

Kearney MS, Stevenson JC (1991) Island land loss and marsh vertical accretion rate evidence for historical sea-level changes in Chesapeake Bay. J Coast Res 7:403-415

Keddy PA (2000) Wetland Ecology. Principle and conversation. Cambridge University Press, Cambridge

Lal R (2001) Soil carbon sequestration and greenhouse effect. Soil Science Society of America. Madison, Special Pub. No. 57

Lal R (2004) Soil carbon sequestration to mitigate climate change. Geoderma 123:1-22

Li C, Swenson E, Weeks E, White JR (2009a) Asymmetric Tidal Straining across an Inlet: Lateral Inversion and Variability over a Tidal Cycle. Estuar Coast Shelf Sci 85:651-660

Li C, Weeks E, Rego J (2009b) In Situ Measurements of Saltwater Flux through Tidal Passes of Lake Pontchartrain Estuary by Hurricanes Gustav and Ike in September 2008. Geophys Res Lett 36:L19609

Li C, White JR, Chen C, Lin H, Weeks E, Galvan K et al (2011) Summertime tidal flushing of Barataria bay: transports of water and suspended sediments. J Geophys Res 116:C04009. doi:10.1029/2010JC006566

McCaffrey RJ, Thomson J (1980) A record of the accumulation of sedimentation and trace metals in a Connecticut salt marsh. Adv Geophys 22:165-236

McKee KL, Cherry JA (2009) Hurricane Katrina sediment slowed elevation loss in subsiding brackish marshes of the Mississippi River Delta. Wetlands 29:2-15 
Mendelssohn IA, Morris JT (2000) Eco-physiological control on the productivity of Spartina alterniflora Loisel. In: Weinstein MP, Kreeger DA (eds) Concepts and controversies in tidal marsh ecology. Kuwer, Boston, pp 59-80

Morton RA, Bernier JC, Kelso KW, Barras JA (2010) Quantifying large-scale historical formation of accommodation in the Mississippi Delta. Earth Surf Processes Landf 35:1625-1641

Neubauer SC (2008) Contributions of mineral and organic components to tidal freshwater marsh accretion. Estuar Coast Shelf Sci 78:78-88

Nyman JA, DeLaune RD (1999) Four potential impacts of global sea-level rise on coastal marsh stability. Curr Top Wetl Biogeochem 3:112-117

Nyman JA, DeLaune RD, Patrick WH Jr (1990) Wetland soil formation in the rapidly subsiding Mississippi River Deltaic Plain: mineral and organic matter relationships. Estuar Coast Shelf Sci 31:57-69

Nyman SA, DeLaune RD, Pezeshki SR, Patrick WH Jr (1995) Organic matter fluxes and marsh stability in a rapidly subsiding estuarine marsh. Estuaries 113:207-218

Nyman JA, Walters RJ, DeLaune RD, Patrick WH Jr (2006) Marsh vertical accretion via vegetative growth. Estuar Coast Shelf Sci 69:370-380

Orson R, Panageotou W, Leatherman SP (1985) Response of tidal salt marshes of the U.S. Atlantic and Gulf Coasts to rising sea level. J Coast Res 1:29-37

Parkinson RW, White JR (1993) Late Holocene erosional shoreface retreat within a siliciclastic-tocarbonate transition zone, east central Florida, USA. J Sediment Res B64:408-415

Parkinson RW, DeLaune RD, White JR (1994) Holocene sea-level rise and the fate of mangrove forests within the Wider Caribbean Region. J Coast Res 10:1077-1086

Patrick WH Jr., DeLaune RD (1990) Subsidence, accretion and sea level rise in South San Francisco Bay marshes. Limnol Oceanogr 35:1389-1395

Pearsall S, Poulter B (2005) Adapting lowlands to rising seas. In: Groom M, et al (eds) Principles of conservation biology. Sinauer, Sunderland

Rabenhorst MC (1995) Carbon storage in tidal marsh soils. In: Lal R, et al (eds) Soil and global change. CRC, Boca Raton

Rahmstorf S (2007) A semi-empirical approach to projecting sea level rise. Science 315:368-370

Redfield AC (1972) Development of a New England salt marsh. Ecol Monogr 42:201-237

Rejmanek M, Stumpf CE, Peterson G (1988) Hurricane induced sedimentation deposition in a Gulf coast marsh. Estuar Coast Shelf Sci 27:217-222

Rybczyk J, Cahoon D (2002) Estimating the potential for submergence for two wetlands in the Mississippi River delta. Estuaries 25:985-989

Salinas LM, DeLaune RD, Patrick WH Jr (1986) Changes occurring along a rapidly subsiding coastal area: Louisiana, USA. J Coast Res 2:269-284

Sampere TA, Bianchi TS, Wakeham SG, Allison MA (2008) Source of organic matter in surface sediment of the Louisiana continental margin: Effect of major depositional/transport pathways and Hurricane Ivan. Cont Shelf Res 28:247-248

Sandor RL, Skees JR (1999) Creating a market for carbon emissions: opportunities for U.S. farmers. Choices: Mag Food, Farm, Resour Issues 14:13-17

Smith CJ, DeLaune RD, Patrick WH Jr (1983) Carbon dioxide emission and carbon accumulation in coastal wetlands. Estuar Coast Shelf Sci 17:12-29

Stevenson FJ, Cole MA (1999) Cycles of soil, 2nd edn. Wiley, New York

Stumpf RP (1983) The process of sedimentation on the surface of a salt marsh. Estuar Coast Shelf Sci 17:495-508

Twilley RR, Chen RH, Hargis T (1992) Carbon sinks in mangroves and their implications to carbon budget of tropical coastal ecosystems. Water Air Soil Pollut 64:265-288

Visser JM, Kaiser C, Hossain I, Couvillion BR, Owens AB (2008) Forecasting 50-years of landscape change in Coastal Louisiana: no increased action \& preliminary draft master plan, chapter 3. In: Twilley RR (ed) Coastal Louisiana ecosystem assessment \& restoration (CLEAR) program: a tool to support coastal restoration, vol IV. Final Report to Department of Natural Resources, Coastal Restoration Division, Baton Rouge, LA. Contract No. 2512-06-02

White JR, Reddy KR (2000) Influence of phosphorus loading on organic nitrogen mineralization of Everglades soil. Soil Sci Soc Am J 64:1525-1534

White JR, Reddy KR (2001) Effect of select inorganic electron acceptors on organic nitrogen mineralization in northern Everglades soils. Soil Sci Soc Am J 65:941-948 
White JR, DeLaune RD, Li CY, Bentley SJ (2009a) Sediment methyl and total mercury concentrations along the Georgia and Louisiana inner shelf, USA. Anal Lett 42:1219-1231

White JR, Fulweiler RW, Li CY, Bargu S, Walker ND, Twilley RR et al (2009b) Mississippi River Flood of 2008: Observations of a large freshwater diversion on physical, chemical, and biological characteristics of a shallow, estuarine lake. Environ Sci Technol 43:5599-5604

Wilson CA, Allison MA (2008) An equilibrium profile model for retreating marsh shorelines in southeast Louisiana. Estuar Coast Shelf Sci 80:483-494

Young DR (1995) Coastal wetland dynamics in response to sea-level rise: transgression and erosion. Duke Univ, Durham 